\title{
APPLICABILITY OF LASER DIFFRACTION ANALYSES IN SOIL PHYSICS PRACTICE
}

\author{
ANDRÁS MaKó ${ }^{1}$, JózSef Szabó ${ }^{1}$, Zsófia BAKACSI ${ }^{1}$, SÁNdOR KoóS ${ }^{1}$, \\ GABRIELla HAUK ${ }^{2}$, HeNRIETTA JANEK ${ }^{3}$, KÁlmÁN RAJKAI ${ }^{1}$, GYÖNGYi BARNA ${ }^{1}$ \\ ${ }^{1}$ HAS CAR Institute for Soil Science and Agricultural Chemistry, \\ 1022 Budapest, Herman Ottó út 15., Hungary; \\ ${ }^{2}$ MOTIM Zrt., 9200 Mosonmagyaróvár, Timföldgyári u. 9., Hungary; \\ ${ }^{3}$ Óbuda University, Rejtő Sándor Faculty of Light Industry \\ and Environmental Engineering, 1034 Budapest, Doberdó u. 6., Hungary; \\ mako_andras@rissac.hu
}

\begin{abstract}
In this research we present the first results how can be used laser diffraction measurement in soil physics practice. The main goals are understanding differences of particle size distribution (PSD) measurments, developing converting methods of PSD data of different determinations. In order to realization of this survey a representative soil database of Hungarian soil types was built up. We compared PSDs of 157 soil samples measured with sieve-pipette method (SPM) and laser diffractometer technique (Malvern Mastersizer 2000) (LDM). Soil textural classes were also determined using the USDA texture triangle.

We used the clay/silt fraction boundary values (clay $<0.0066 \mathrm{~mm}$; silt: $0.0066-0.05 \mathrm{~mm}$ ) introduced for the LDM data in order to take them comparable to PSD data determined by the SPM: We got higher similarities of clay and silt fractions of the modified size boundary values. For the used dataset correspondence of texture classes derived from SPM and LDM PSD data, however is not higher than $60 \%$.
\end{abstract}

Keywords: soil, particle size distribution, laser diffraction, pipette method

\section{INTRODUCTION}

Particle size distribution (PSD) is one of the main soil physical properties. It determines many other characteristics, such as water retention, hydraulic conductivity, pore size distribution, aggregate stability, Atterberg limits, microbial activity, as well (e.g. WÖsTEN ET AL., 2001; LAMORSKI ET AL., 2014).

Measuring the sand, silt and clay fractions can be done by different methods, like sieving (mainly sand size particles), sedimentation (with hydrometer or pipette methods), or with laser diffractometer method (LDM) (KONERT AND VANDENBERGHE, 1997; RYŻAK AND BIEGANOWSKI, 2010; LAMORKSI ET AL., 2014). LDM is becoming more often used in soil science, but its application has not yet replaced the labour-intensive pipette or hydrometer procedures. In PSD determining methods different pre-treatments are used for removing the cementing and flocculating agents - such as calcium carbonate, organic matter, iron oxides. Different pre-treatments may produce different PSD data (RYŻAK AND BIEGANOWSKI, 2010; MAKÓ ET AL., 2014a,b). Different PSD standards use different particle size limit (NEMES ET AL., 1999) which can also cause diverse results (KONERT AND VANDENBERGHE, 1997; NEMES AND RAWLS, 2006). LDM usually measures (underestimates) smaller clay fraction values than the conventional methods (KONERT AND VANDENBERGHE, 1997; POLAKOWSKI ET AL., 2014).

There are intentions all around the world to harmonize the PSD data by the LDM measurements to that of the sedimentation techniques (pipette or hydrometer methods). Unfortunately, up to the applied methodology (e. g. type of pre-treatments, kind of dispersant etc.), PSDs of the sedimentation methods (due to different standards) are dissimilar and could be hardly harmonized with each other, as well. A need was arisen 
therefore to build up a database, containing PSD values measured by the pipette method according to the Hungarian standard (MSZ-08. 0205: 1978) (henceforward SPM) and the LDM according to a widespread and widely used procedure.

In this publication we compared the PSD of 157 soil samples measured by SPM and LDM.

\section{MATERIAL AND METHOD}

The 157 soil samples originated from different layers of 53 soil profiles, collected in Tokaj Region, North-Hungary in 2014 and 2015 (Fig. 1). Samples are mainly from forest soils.

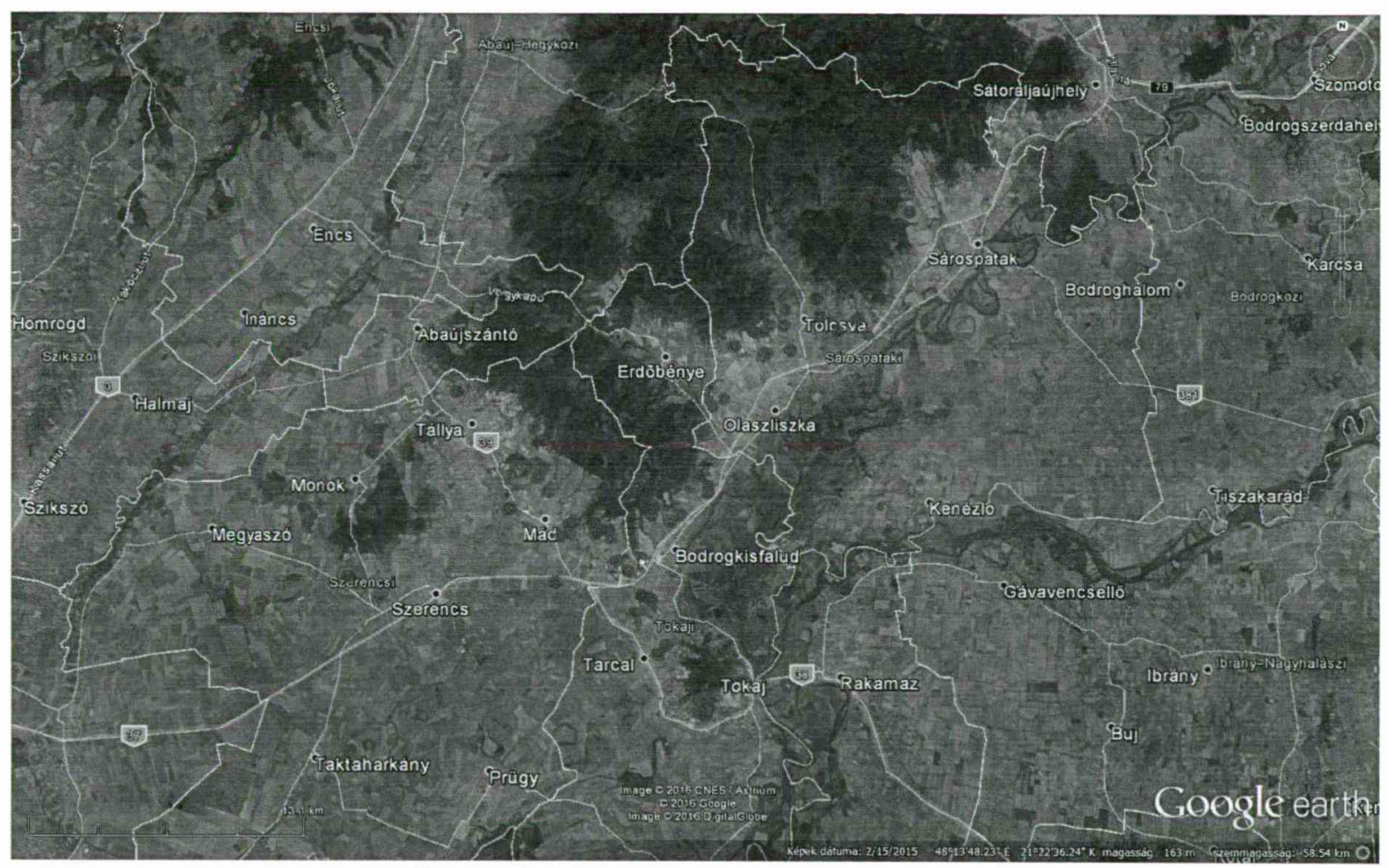

Figure 1. Map of soil sampling points

Particle size distribution measurements with SPM were carried out. Coarse sand particles were separated by $0.25 \mathrm{~mm}$ sieve. Sodium pyrophosphate solution was used as dispersing agent.

PSD measurements with LDM were carried out by Mastersizer 2000 (Malvern Ltd), in Hydro $2000 \mathrm{G}$ dispersion unit at least two repetition, with the following settings: rotation speed: $700 \mathrm{rpm}$; ultrasonic: 75\%, 4 minutes; dispersant solution: $33 \mathrm{~g}$ sodiumhexametaphosphate $+7 \mathrm{~g}$ sodium-bicarbonate/L; absorption index: 0.1 ; refractive index: 1.52 .

Based on previous experiences (on the grounds of Hungarian and European soil databases (MAKÓ ET AL., 2014b; BARNA ET AL., 2015)) and results of KONERT AND VANDENBERGHE (1997), we modified the size limits of clay and silt fractions measured by the LDM (Table 1). Clay fraction is counted under $0.0066 \mathrm{~mm}$, silt fraction ranges between 0.0066 and 0.05 $\mathrm{mm}$. 
Table 1. Size limits of particle-size fractions (mm)

\begin{tabular}{|c|c|c|c|}
\cline { 2 - 4 } \multicolumn{1}{c|}{} & clay & silt & sand \\
\hline SPM & $<0.002$ & $0.002-0.05$ & $0.05-2$ \\
\hline LDM_original & $<0.002$ & $0.002-0.05$ & $0.05-2$ \\
\hline LDM_modified & $<0.0066$ & $0.0066-0.05$ & $0.05-2$ \\
\hline
\end{tabular}

From the measured sand, silt and clay fractions, either with the modified size limits, soil texture was determined according to USDA texture triangle. Texture classes were compared: in how many cases match the pipette method and the LDM.

\section{RESULTS}

The results of 325 particle size distribution (PSD) measurements were compared (Figure $2-4)$. In Figure 2 the comparison of clay fraction is shown measured by the pipette method and the LDM, and characterised with different particle size limits (Table 1). In case of modified particle-size limits a little bit stronger correlation was found between pipette method and LDM. The modified particle-size limits resulted in a much smaller underestimation of clay fraction.

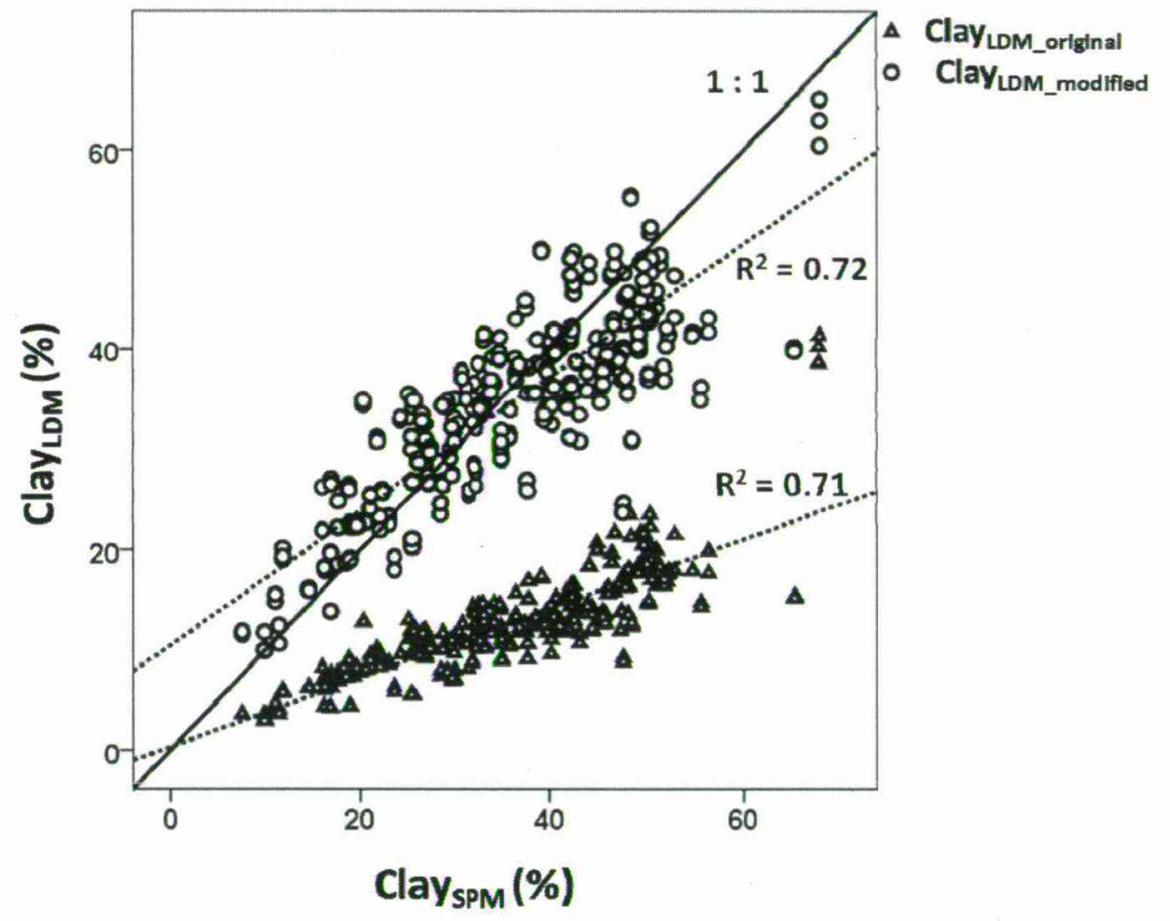

Figure 2. Comparison of clay fractions measured by different methods and characterised with different particle-size boundary

With the modified silt size lower limit similarity increased between the pipette method and the LDM data. The highest improvement was experienced here, the correlation coefficient $\left(\mathrm{R}^{2}\right)$ increased from 0.46 to 0.740 (Figure 3). 


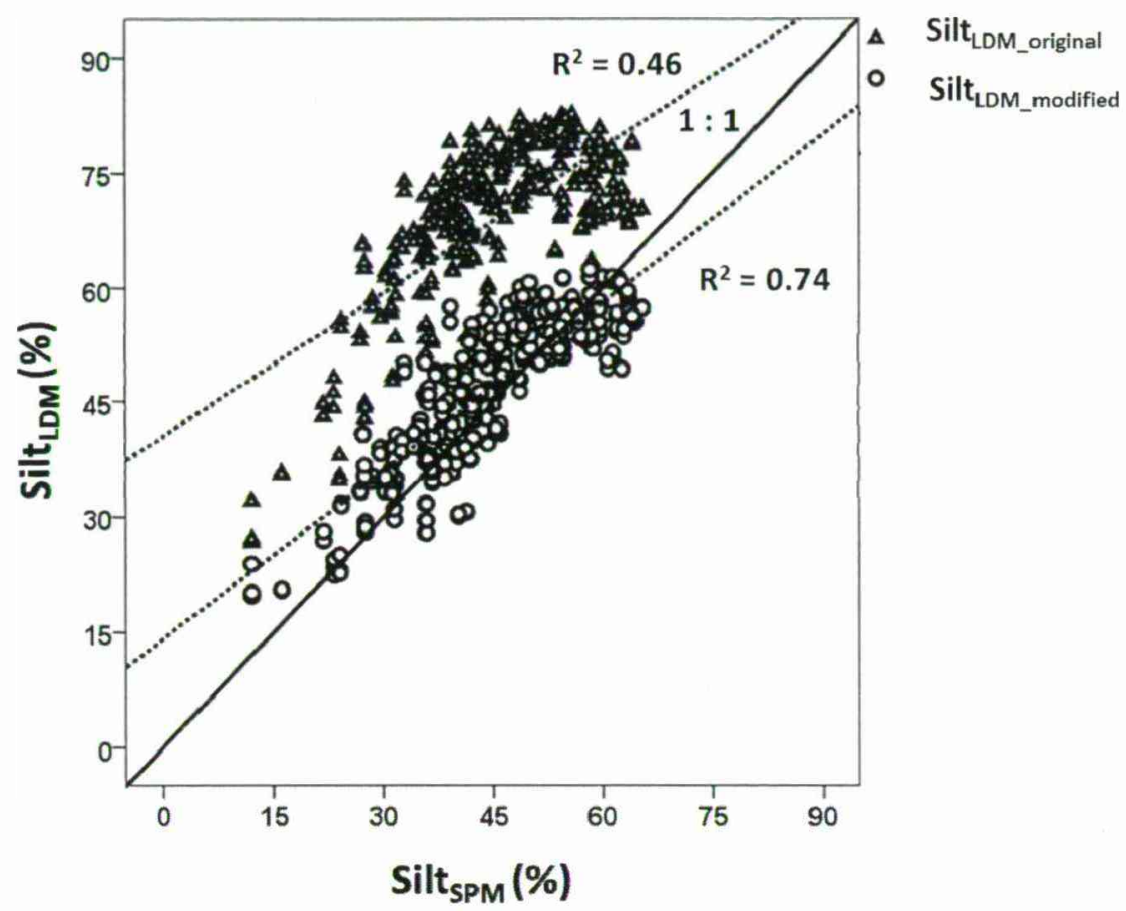

Figure 3. Comparison of silt fraction measured by different methods and characterised with different particle-size boundary

The two kinds of methods measure nearly same sand content (Figure 4).

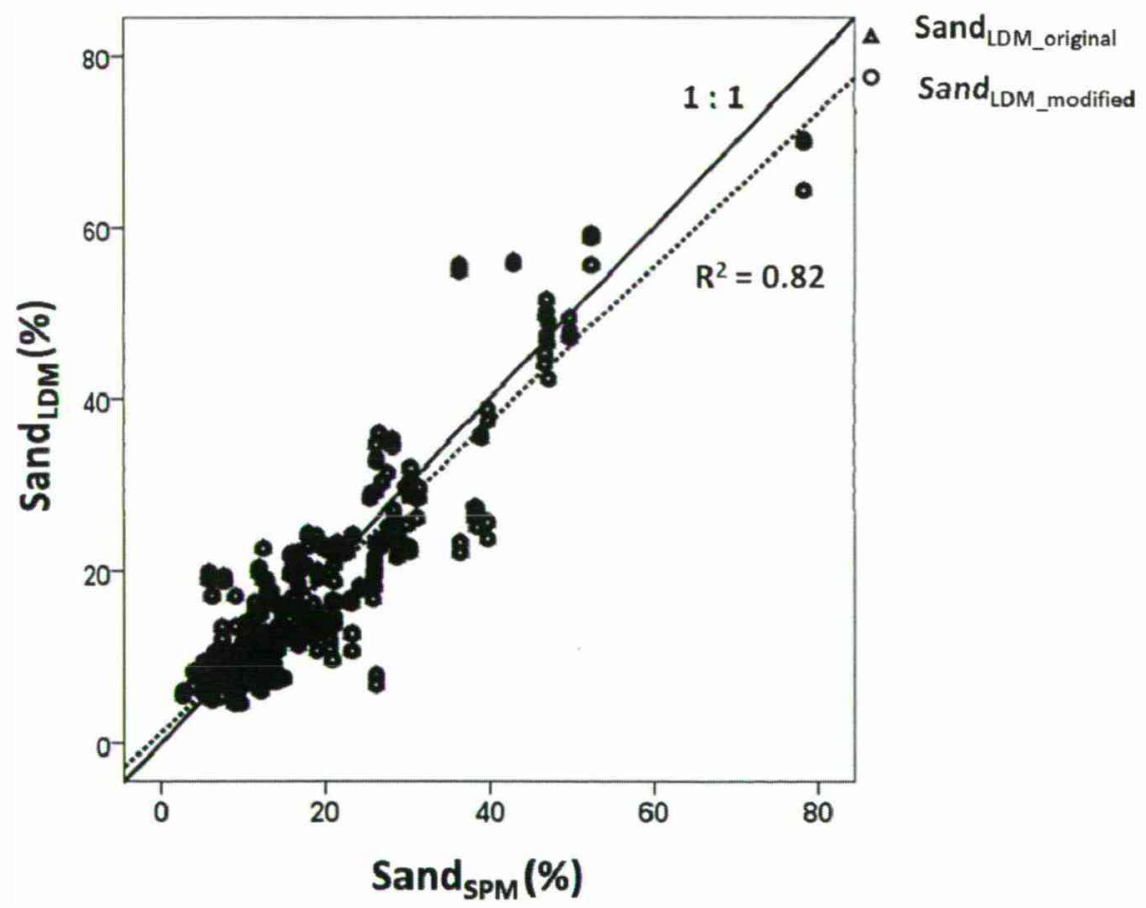

Figure 4. Comparison of sand fraction measured by different PSD methods

The match between soil texture categories, which were determined according to the USDA texture triangle, was significantly better in case of using the modified particle-size limits for the LDM (Table 2). Confusion matrixes (Table 2) illustrating the accuracy in correctly assigning the textural class of the measurements starting from either LDM data (original or modified clay/silt boundary) or sieve-pipette method (SPM) measured data. 
Table 2. Confusion matrixes of textural classes' accuracy

\begin{tabular}{|c|c|c|c|c|c|c|c|c|c|c|c|}
\hline & \multicolumn{9}{|c|}{ PSD $_{\text {SPM }}$} & \multirow[b]{2}{*}{ Total } \\
\hline & & $\mathrm{C}$ & $\mathrm{CL}$ & $\mathrm{L}$ & SACL & SAI & SI & SIL & $\mathrm{SC}$ & SICL & \\
\hline \multirow{10}{*}{ 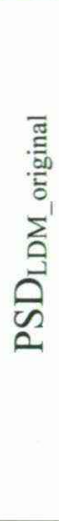 } & $\mathrm{C}$ & 0 & 0 & 0 & 0 & 0 & 0 & 0 & 0 & 0 & \multirow{9}{*}{$19 \%$} \\
\hline & CL & 0 & 0 & 0 & 0 & 0 & 0 & 0 & 0 & 0 & \\
\hline & $\mathrm{L}$ & 0 & 0 & 0 & 2 & 0 & 0 & 0 & 0 & 0 & \\
\hline & SACL & 0 & 0 & 0 & 0 & 0 & 0 & 0 & 0 & 0 & \\
\hline & SAL & 2 & 0 & 7 & 6 & 3 & 0 & 0 & 0 & 0 & \\
\hline & SI & 0 & 0 & 1 & 0 & 0 & 0 & 2 & 1 & 7 & \\
\hline & SIL & 62 & 34 & 12 & 0 & 0 & 0 & 58 & 70 & 55 & \\
\hline & $\mathrm{SC}$ & 2 & 0 & 0 & 0 & 0 & 0 & 0 & 0 & 0 & \\
\hline & SICL & 1 & 0 & 0 & 0 & 0 & 0 & 0 & 0 & 0 & \\
\hline & Total & 67 & 34 & 20 & 8 & 3 & 0 & 60 & 71 & 62 & 325 \\
\hline
\end{tabular}

PSDSPM

\begin{tabular}{|c|c|c|c|c|c|c|c|c|c|c|c|c|}
\hline & & & & & & & & & & \multirow{2}{*}{\multicolumn{2}{|c|}{ Total }} \\
\hline & & $\mathrm{C}$ & $\mathrm{CL}$ & $\mathrm{L}$ & SACL & $\mathrm{SAL}$ & SI & SIL & $\mathrm{SC}$ & SICL & & \\
\hline \multirow{10}{*}{$\overline{2}$} & $\mathrm{C}$ & 26 & 1 & 0 & 0 & 0 & 0 & 0 & 6 & 2 & 35 & \multirow{10}{*}{$57 \%$} \\
\hline & $\mathrm{CL}$ & 8 & 20 & 3 & 0 & 0 & 0 & 1 & 0 & 1 & 33 & \\
\hline & $\mathrm{L}^{\cdot}$ & 0 & 4 & 12 & 4 & 0 & 0 & 0 & 0 & 0 & 20 & \\
\hline & SACL & 2 & 0 & 0 & 1 & 0 & 0 & 0 & 0 & 0 & 3 & \\
\hline & SAL & 0 & 0 & 2 & 3 & 3 & 0 & 0 & 0 & 0 & 8 & \\
\hline & SI & 0 & 0 & 0 & 0 & 0 & 0 & 0 & 0 & 0 & 0 & \\
\hline & SIL & 0 & 1 & 1 & 0 & 0 & 0 & 43 & 0 & 3 & 48 & \\
\hline & $\mathrm{SC}$ & 22 & 3 & 0 & 0 & 0 & 0 & 0 & 26 & 3 & 54 & \\
\hline & SICL & 9 & 5 & 2 & 0 & 0 & 0 & 16 & 39 & 53 & 124 & \\
\hline & Total & 67 & 34 & 20 & 8 & 3 & 0 & 60 & 71 & 62 & 325 & \\
\hline
\end{tabular}

C:clay; CL: clay loam; L: loam, SACL: sandy clay loam; SAL: sandy loam; SI: silt; SIL:silty loam; SC: sandy clay; SICL: silty clay loam.

\section{CONCLUSIONS}

Applying usual size limits at the LDM, clay fraction was underestimated and silt fraction was overestimated compared to the pipette method, as international literature established, as well. Extension of particle-size limit of clay fraction from 0.002 to $0.0066 \mathrm{~mm}$, and so changing the size limit of silt fraction to $0.0066-0.05 \mathrm{~mm}$, causes more easy comparability and closer similarity between results of SPM and LDM. KONERT AND VANDENBERGHE (1997), MAKÓ ET AL. (2014a,b) and BARNA ET AL. (2015) got similar results. Comparability at $0.008 \mathrm{~mm}$ clay boundary (advised by KONERT AND VANDENBERGHE (1997)) was not as good as at $0.0066 \mathrm{~mm}$ (recommended by MAKÓ ET AL. $(2014 a, b)$ either in national, or in continental scale (results not shown). This change of fraction boundary can be the first step in conversion of results of different PSD methods. Subsequently soil texture classes determined from the LDM measurements significantly differ from results of the SPM, correspondence of texture classes is less than $60 \%$. Therefore LDM analyses, even with modified fraction boundary, are not suitable for soil texture classification (TAUBNER ET AL., 2009; BARNA ET AL., 2015). 
However, the used database size is still not enough for optimizing the particle fraction size limits. Further investigation will be carried out on a more detailed Hungarian database to harmonize PSDs of measuring methods.

\section{ACKNOWLEDGEMENTS}

The authors would like to gratefully acknowledge Hilda Hernádi (University of Pannonia) for her help and contribution.

\section{REFERENCES}

Barna, Gy., Szabó, J., BaKacsi, Zs., Koós, S., LÁszló, P., HauK, G., RaJKai, K., MaKó, A. (2015): Effect of particle size limit values on predicted soil hydraulic conductivity. In Proc. of "Transport of Water, Chemicals and Energy in the Soil-Plant-Atmosphere System". 22 ${ }^{\text {nd }}$ Poster day. Institute of Hydrology of SAS. Bratislava, November 12, 2015. (Ed.: ČElKovÁ, A.). 16-23.

KONERT, M., VANDENBERGHE, J. (1997): Comparison of laser grain size analysis with pipette and sieve analysis: a solution for the underestimation of the clay fraction. Sedimentology 44: 523-535.

Lamorski, K., Bieganowski, A., RyzaK, M., Sochan, A., SŁawinski, C., Stelmach, W. (2014): Assessment of the usefulness of particle size distribution measured by laser diffraction for soil water retention modelling. Journal of Plant Nutrition and Soil Science 177: 803-813.

MAKó, A., RAJKAI, K., HERnÁdi, H., HAUK, G. (2014a): Comparison of different settings and pre-treatments in soil particle size distribution measurement by laser-diffraction method. Agrokémia és Talajtan 63: 19-28.

Makó, A., Tóth, G., Hernádi, H., Tóth, B., HaUK, G. (2014b): Lézeres szemcseanalizátorral történő talajfizikai mérések hazai és nemzetközi tapasztalatai. Magyar Talajtani Társaság, Talajfizikai Szakosztály ülés. MTA ATK TAKI. 2014. V. 16. MSZ-08. 0205:1978. A talaj fizikai és vízgazdálkodási tulajdonságainak vizsgálata.

Nemes, A., Wösten, J.H.M., Lilly, A., Oude VoshaAR, J.H. (1999): Evaluation of different procedures to interpolate particle-size distributions to achieve compatibility within soil databases. Geoderma 90: 187-202.

NEMES, A., RAwLS, W.J. (2006): Evaluation of different representations of the particle-size distribution to predict soil water retention. Geoderma 132: 47-58.

Polakowski, C., Sochan, A., Bieganowski, A., Ryzak, M., FöldÉnyi, R., Tóth, J. (2014): Influence of the sand particle shape on particle size distribution measured by laser diffraction method. International Agrophysics 28: 195-200.

RYŻAK, M., BIEGANOWSKI, A. (2010): Determination of particle size distribution of soil using laser diffraction-Comparison with areometric method. International Agrophysics 24: $177-181$.

TAUBNER, H., ROTH, B., TIPPKÖTTER, R. (2009): Determination of soil texture: Comparison of the sedimentation method and the laser-diffraction analysis. Journal of Plant Nutrition and Soil Science 172: 161-171.

WÖSTEN, J.H.M., PACHEPSKY, Y.A., RAWLS, W.J. (2001): Pedotransfer functions: bridging the gap between available basic soil data and missing soil hydraulic characteristics. Journal of Hydrology 251: 123-150. 